$\begin{array}{rr}\text { FIT(1)PATOLOGI } & \text { Volume 11, Nomor 6, Desember 2015 } \\ \text { I N D ON E IA } & \text { Halaman 205-210 } \\ \text { ISSN: } 0215-7950 & \text { DOI: } 10.14692 / \text { jfi.11.6.205 }\end{array}$

\title{
Identifikasi Virus Penyebab Penyakit Kerdil pada Tanaman Padi di Sukamandi, Jawa Barat
}

\author{
Identification of Viruses Causing Stunting Diseases on Rice \\ in Sukamandi, West Java
}

\author{
Amelia Feryna Bulan Dini, I Wayan Winasa, Sri Hendrastuti Hidayat* \\ Institut Pertanian Bogor, Bogor 16680
}

\begin{abstract}
ABSTRAK
Penyakit tanaman padi yang disebabkan oleh virus merupakan kendala penting bagi produksi beras di Indonesia. Penelitian dilakukan untuk menentukan insidensi penyakit kerdil di daerah Sukamandi, Kabupaten Subang, Jawa Barat, mengidentifikasi penyebab penyakit kerdil dengan metode RT-PCR dan perunutan gen protein selubung. Berdasarkan hasil pengamatan di lapangan, insidensi penyakit kerdil tergolong rendah (0.01-10.52\%) selama pengamatan periode November-Desember 2014. Gejala penyakit yang ditemukan, yaitu gejala kerdil hampa, gejala kerdil rumput, dan gejala campuran kerdil hampa dan kerdil rumput. Pita DNA spesifik gen protein selubung Rice ragged stunt virus (RRSV) dan Rice grassy stunt virus (RGSV) berhasil diamplifikasi. Analisis sikuen nukleotida menunjukkan bahwa RRSV dan RGSV isolat Subang memiliki homologi tertinggi berturut-turut dengan RRSV isolat Vietnam, Filipina, dan Thailand (97.1 \%), dan RGSV isolat Longan, Vietnam (95.8 \%).
\end{abstract}

Kata kunci : insidensi penyakit, Rice grassy stunt virus, Rice ragged stunt virus, sikuen nukleotida

\begin{abstract}
Viral diseases on rice is an important constraint for rice production in Indonesia. Research was conducted to determine the incidence of stunting disease in Sukamandi area at Subang regency (West Java), to identify the virus associated with the disease using RT-PCR method, and to analyze coat protein gene sequences. Field observation during growing period on November- December 2014 indicated that the incidence of stunting disease was low (0.01-10.52\%). Grassy stunt and ragged stunt symptoms was observed in the fields. Spesific DNA fragments of coat protein gene of Rice ragged stunt virus (RRSV) and Rice grassy stunt virus (RGSV) was successfully amplified using specific primers. Nucleotide sequence analysis showed that RRSV and RGSV isolates from Subang has the highest homology with RRSV isolates from Vietnam, Philipines and Thailand (97.1\%) and RGSV isolate from Longan, Vietnam (95.8\%), respectively.
\end{abstract}

Key words : disease incidence, Rice grassy stunt virus, Rice ragged stunt virus, sequence nucleotide

*Alamat penulis korespondensi: Departemen Proteksi Tanaman, Fakultas Pertanian, Institut Pertanian Bogor. Jalan Kamper, Kampus Darmaga IPB, Bogor 16680

Tel: 0251-8629364, Faks: 0251-8629362, Surel: srihendrastutihidayat@gmail.com 


\section{PENDAHULUAN}

Indonesia merupakan negara konsumen dan juga penghasil beras ketiga di dunia setelah Cina dan India. Wereng batang cokelat (Nilaparvata lugens) merupakan serangga hama yang banyak menimbulkan kerugian pada tanaman padi di Indonesia. Selain itu, wereng batang cokelat juga berperan sebagai vektor penyakit kerdil hampa dan kerdil rumput sehingga menyebabkan kerusakan yang lebih besar (Cabautan et al. 2009)

Penyakit kerdil rumput yang disebabkan oleh Rice grassy stunt virus (RGSV) dilaporkan pertama kali di Indonesia tahun 1971 dan disebut sebagai kerdil rumput tipe I, kemudian pada tahun 2006 ditemukan penyakit kerdil rumput tipe II. Gejala penyakit kerdil rumput diantaranya tanaman menjadi sangat kerdil, anakan banyak, daun hijau pucat sampai kuning atau daun-daun sempit berwarna kuning sampai oranye, dan daun sempit dengan bintik-bintik karat kecil (IRRI 2002). Penyakit kerdil hampa pada padi yang disebabkan oleh Rice ragged stunt virus (RRSV), dilaporkan pertama kali di Indonesia pada tahun 1976 (Chen dan Chiu 1982). Tanaman padi yang terserang penyakit kerdil hampa mengalami hambatan pertumbuhan (kerdil), daun menjadi berwarna gelap dengan tepi bergerigi atau ujung memutar, dan tulang daun mengalami pembengkakan atau benjolan di bagian bawah helai daun dan bagian luar permukaan pelepah daun (Cabautan et al. 2009).

Diagnosis penyakit kerdil tidak dapat mengandalkan hanya dari gejala saja karena gejala yang muncul beranekaragam serta mirip dengan gejala kekurangan unsur hara dan kekeringan. Penggunaan teknik molekuler dengan metode polymerase chain reaction (PCR) telah dilaporkan berhasil untuk mendeteksi virus penyebab penyakit tungro dan kerdil (Uehara-Ichiki et al. 2013). Oleh karena terjadi peningkatan serangan wereng batang cokelat di lapangan akhir-akhir ini, maka perlu dilakukan pemutakhiran data virus penyebab kerdil padi.

Penelitian dilakukan dengan tujuan menentukan insidensi penyakit kerdil pada salah satu sentra penanaman padidiSukamandi,
Kabupaten Subang dan mengidentifikasi penyebab penyakit kerdil dengan deteksi asam nukleat menggunakan metode RT-PCR dan perunutan DNA gen protein selubung.

\section{BAHAN DAN METODE}

\section{Pengamatan Insidensi Penyakit Padi di Lapangan}

Pengamatan dilakukan di lahan penanaman padi milik Balai Besar Penelitian Padi di Desa Sukamandi, Kecamatan Patok Beusi, Kabupaten Subang, Provinsi Jawa Barat. Petak pengamatan berjumlah 3 plot, masingmasing berukuran $300 \mathrm{~m}^{2}$ yang terdiri atas 4320 rumpun. Insidensi penyakit dihitung dengan rumus :

$$
\mathrm{IP}=\frac{\mathrm{n}}{\mathrm{N}} \times 100 \%, \text { dengan }
$$

IP, insidensi penyakit (\%); n, jumlah tanaman terserang; $\mathrm{N}$, jumlah seluruh tanaman yang diamati.

Pengamatan dimulai sejak umur tanaman 1 minggu setelah tanam (MST) sampai 8 MST dengan interval 7 hari. Gejala penyakit kerdil yang diamati mencakup gejala kerdil rumput dan atau kerdil hampa seperti penyempitan daun, warna daun berubah menjadi hijau pucat, adanya daun menggulung, penurunan tinggi tanaman, jumlah anakan yang lebih banyak, dan adanya pembengkakan pada pangkal daun.

\section{Deteksi virus dengan metode RT-PCR}

Tahapan deteksi terdiri atas ekstraksi RNA total, sintesis cDNA, dan amplifikasi DNA target. Ekstraksi RNA total dilakukan dengan metode Cetyl Trimethyl Ammonium Bromide (CTAB) (Doyle dan Doyle 1990). Sintesis cDNA menggunakan RNA total sebagai templat dalam reaksi transkripsi balik (reverse transcription/RT). Reaksi RT dilakukan dengan total volume $10 \mu \mathrm{L}$ terdiri atas $2 \mu \mathrm{L}$ bufer RT, $1 \mu \mathrm{L}$ dNTP $10 \mathrm{mM}, 1 \mu \mathrm{L}$ DTT $50 \mathrm{mM}, 0.50 \mu$ LRNAse Inhibitor (Thermo Scientific, US), $0.50 \mu \mathrm{L}$ M-MuLV (Thermo Scientific, US), $2 \mu \mathrm{L} \mathrm{H}_{2} \mathrm{O}$ bebas nuklease, $1 \mu \mathrm{L}$ Oligo d(T) 10 mM, dan $2 \mu$ L RNA total. Tahap sintesis cDNA diawali dengan mencampurkan RNA total dan Oligo d(T), kemudian campuran diinkubasi dalam penangas air selama 5 menit 
pada suhu $65^{\circ} \mathrm{C}$ dan segera didinginkan dengan meletakkan tabung mikro dalam es. Bahan pereaksi lainnya kemudian ditambahkan ke dalam tabung mikro, selanjutnya tabung mikro disentrifugasi selama 1 menit dengan kecepatan $1000 \mathrm{rpm}$. Tabung mikro diinkubasi pada suhu $42{ }^{\circ} \mathrm{C}$ selama 60 menit, selanjutnya diinkubasi pada suhu $70{ }^{\circ} \mathrm{C}$ selama 5 menit untuk inaktivasi enzim.

Amplifikasi DNA target dilakukan dalam total volume $25 \mu \mathrm{L}$, terdiri atas $1 \mu \mathrm{L}$ cDNA, $1 \mu \mathrm{L}$ primer $\mathrm{F} 10 \mu \mathrm{M}, 1 \mu \mathrm{L}$ primer $\mathrm{R} 10 \mu \mathrm{M}$, 12.5 $\mu \mathrm{L}$ GTG Master mix, dan $9.5 \mu \mathrm{L}$. Primer yang digunakan untuk amplifikasi RGSV, yaitu primer RGSV-S3-F (5'-AGAATTTTTATGTCACTTAG-3') dan RGSV-S3-R (5'-TATCCA GATTCCAG GTGC-3') dengan target amplikon \pm 738 bp (IRRI 2002). RRSV diamplifikasi secara parsial menggunakan primer spesifik gen protein selubung RRSV-S9-F (5'-TGA AGCGCTCGGAACCAA-3')danRRSV-S9-R (5'-GCGTCTAGTCCCGTATGG-3') dengan target amplikon $\pm 445 \mathrm{bp}$.

Amplikasi cDNA dimulai dengan tahapan pradenaturasi pada suhu $94^{\circ} \mathrm{C}$ selama 5 menit sebanyak 1 siklus, dilanjutkan amplifikasi sebanyak 35 siklus dengan tahapan denaturasi pada suhu $94{ }^{\circ} \mathrm{C}$ selama 1 menit, penempelan primer selama 1 menit pada suhu $50{ }^{\circ} \mathrm{C}$ untuk RGSV (IRRI 2002) atau $56{ }^{\circ} \mathrm{C}$ untuk RRSV berdasarkan optimasi, dan pemanjangan utas baru pada suhu $72{ }^{\circ} \mathrm{C}$ selama 1 menit, dan diakhiri dengan 1 siklus pemanjangan akhir pada suhu $72{ }^{\circ} \mathrm{C}$ selama 7 menit.

Produk amplifikasi DNA diseparasi pada $1 \%$ gel agarosa $0.5 x$ Tris-Borate EDTA (TBE) pada tegangan 50 volt selama 50 menit. Gel agarosa kemudian direndam dalam larutan $0.1 \%$ etidium bromida selama 5 menit. Visualisasi dilakukan di bawah UV transiluminator dan didokumentasi dengan kamera digital.

\section{Perunutan dan Analisis Sikuen Nukleotida}

DNA hasil amplifikasi dirunut sikuennya di First Base, Malaysia. Hasil runutan DNA dianalisis dengan program Basic Local Alaigment Search Tool (BLAST) pada situs National Center for Biotechnology
Information (www.ncbi.nlm.nih.gov) untuk membandingkan sikuen virus target dengan sikuen nukleotida virus asal negara lain yang terdaftar pada Genbank. Tingkat homologi nukleotida dan asam amino diperoleh dengan program ClustalW multiple alignment dan Sequences Identity Matrix menggunakan perangkat lunak Bioedit 7.05.

\section{HASIL}

Insidensi penyakit kerdil pada varietas Mekongga di Sukamandi berkisar antara $0-10.52 \%$. Gejala penyakit kerdil pada pertanaman padi mulai terlihat pada 2 MST dan mengalami peningkatan sampai dengan 7 MST (Tabel 1). Gejala penyakit yang ditemukan pada saat pengamatan terdiri atas gejala kerdil hampa, gejala kerdil rumput, dan gejala campuran kerdil hampa dan kerdil rumput (Gambar 1). Gejala kerdil baru dapat terlihat jelas setelah 5 MST. Gejala penyakit kerdil hampa merupakan gejala yang dominan pada tanaman padi di petak pengamatan. Selain gejala khas penyakit kerdil rumput dan penyakit kerdil hampa, juga ditemukan gejala berupa gabungan gejala kerdil rumput dan kerdil hampa pada tanaman singgang. Populasi wereng batang cokelat sebagai vektor virus kerdil di lapangan mengalami fluktuasi (data tidak ditampilkan).

Deteksi virus dari sampel tanaman mengonfirmasi gejala dengan jenis virus yang menginfeksi. Pita DNA RRSV berukuran $\pm 445 \mathrm{pb}$ berhasil diamplifikasi dari sampel yang menunjukkan gejala kerdil hampa,

Tabel 1 Rata-rata insidensi penyakit kerdil pada petak pengamatan di Sukamandi pada periode Oktober-November 2014

\begin{tabular}{lc}
\hline $\begin{array}{l}\text { Waktu Pengamatan } \\
\text { (MST) }\end{array}$ & $\begin{array}{c}\text { Insidensi Penyakit Kerdil } \\
(\%)\end{array}$ \\
\hline 1 & 0.00 \\
2 & 0.01 \\
3 & 0.05 \\
4 & 0.06 \\
5 & 10.25 \\
6 & 10.27 \\
7 & 10.52 \\
8 & 10.52 \\
\hline
\end{tabular}


sedangkan pita DNA RGSV berukuran $\pm 750 \mathrm{pb}$ berhasil diamplifikasi dari sampel yang menunjukkan gejala kerdil rumput. Dua pita DNA, masing-masing berukuran $\pm 445 \mathrm{pb}$ dan $\pm 750 \mathrm{pb}$, diperoleh dari sampel yang menunjukkan gejala campuran kerdil rumput dan kerdil hampa (Gambar 2).

Gen protein selubung RRSV berhasil dirunut sepanjang $453 \mathrm{pb}$ dari $1132 \mathrm{pb}$ ukuran gen protein selubung dan mengkode 151 asam amino dari 377 total asam amino, sedangkan gen protein selubung RGSV berhasil dirunut sepanjang $738 \mathrm{pb}$ dari $876 \mathrm{pb}$ ukuran gen protein selubung dan mengkode 246 asam amino dari 292 total asam amino. Analisis sikuen nukleotida RRSV menunjukkan bahwa isolat Subang, Indonesia memiliki homologi tertinggi dengan isolat Vietnam, Filipina dan Thailand (97.1 \%) (Tabel 2), sementara RGSV isolat Subang, Indonesia memiliki homologi yang tertinggi dengan isolat Longan, Vietnam $(95.8 \%)$ (Tabel 3).

\section{PEMBAHASAN}

Insidensi penyakit kerdil di Sukamandi, Subang ditentukan oleh populasi serangga vektornya. Daerah Sukamandi (Subang) merupakan sentra padi dengan pola tanam padi secara terus menerus sepanjang tahun tanpa

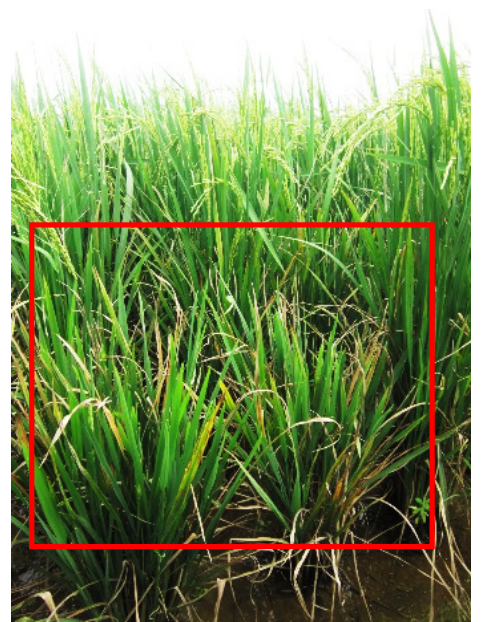

a

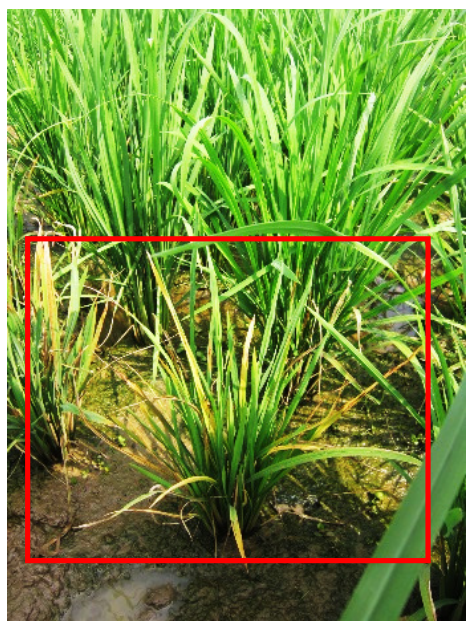

b

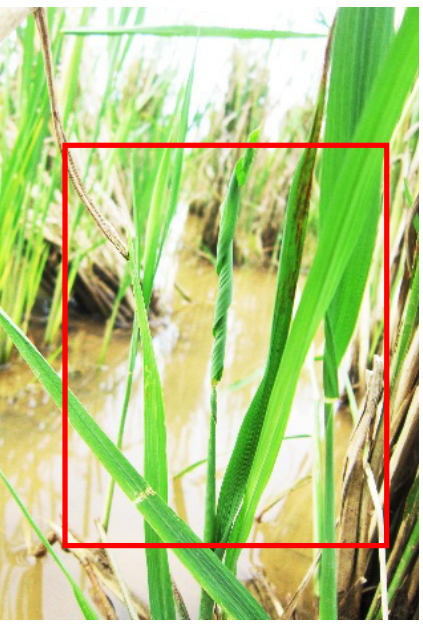

$\mathrm{C}$

Gambar 1 Tanaman padi yang terserang penyakit kerdil diantara tanaman sehat. a. Gejala penyakit kerdil rumput pada tanaman $5 \mathrm{MST}$, b. gejala penyakit kerdil hampa pada tanaman $10 \mathrm{MST}$, c. gejala penyakit kerdil rumput dan kerdil hampa pada tanaman singgang. Kotak merah menunjukkan gejala khas penyakit kerdil.

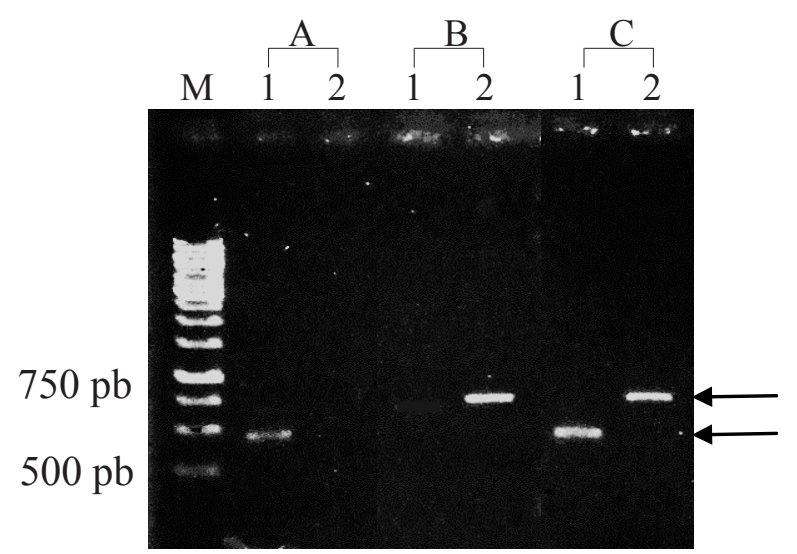

Gambar 2 Visualisasi pita DNA hasil amplifikasi menggunakan pasangan primer RRSV-S9-F/ RRSV-S9-R (1), dan RGSV-S3-F/ RGSV-S3-R (2). M, penanda DNA 1 kpb (Thermoscientific); A, tanaman dengan gejala RRSV; B, tanaman dengan gejala RGSV; C, tanaman dengan gejala campuran RRSV dan RGSV. 
Tabel 2 Tingkat homologi sikuen nukliotida gen protein selubung Rice ragged stunt virus

\begin{tabular}{llccccc}
\hline \multirow{2}{*}{ No } & \multirow{2}{*}{ Asal isolat $^{\mathrm{a}}$} & \multicolumn{5}{c}{ Homologi (\%) $^{\mathrm{b}}$} \\
\cline { 3 - 6 } & & 1 & 2 & 3 & 4 & 5 \\
\hline 1 & Indonesia (Subang) & ID & & & & \\
2 & Vietnam (Angiang) & 97.1 & ID & & & \\
3 & Filipina (Filipina) & 97.1 & 100 & ID & ID & \\
4 & Cina (Fujian) & 96.8 & 99.7 & 99.7 & ID \\
5 & Thailand (Thailand) & 97.1 & 100 & 100 & 99.7 & .
\end{tabular}

aSikuen RRSV pembanding diperoleh dari Genbank : isolat Angiang (GQ329711.1), isolat Filipina (L79969.1), isolat Fujian (HM125547.1), isolat Thailand (L38899.1).

${ }^{\mathrm{b}}$ Tingkat kemiripan sikuen nukleotida RRSV dihitung menggunakan program Bioedit versi 6.05 .

Tabel 3 Tingkat homologi sikuen nukleotida gen protein selubung Rice grassy stunt virus

\begin{tabular}{|c|c|c|c|c|c|c|}
\hline \multirow{2}{*}{ No } & \multirow{2}{*}{ Asal Isolat ${ }^{a}$} & \multicolumn{5}{|c|}{ Homologi $(\%)^{b}$} \\
\hline & & 1 & 2 & 3 & 4 & 5 \\
\hline 1 & Indonesia (Subang) & ID & & & & \\
\hline 2 & Vietnam (TG09-12) & 94.9 & ID & & & \\
\hline 3 & Vietnam (HG09-06) & 95.7 & 98.9 & ID & & \\
\hline 4 & Vietnam (LA11-10) & 95.7 & 98.2 & 98.9 & ID & \\
\hline 5 & Vietnam (Longan) & 95.8 & 98.3 & 99.1 & 99.4 & ID \\
\hline
\end{tabular}

${ }^{a}$ Sikuen RGSV pembanding diperoleh dari Genbank : isolat Vietnam TG09-12 (HE963229.1), isolat Vietnam HG09-06 (HE963226.1), isolat Vietnam LA11-10 (HE963237.1), isolat Longan (FR696598.1).

${ }^{b}$ Tingkat kemiripan sikuen nukleotida RGSV dihitung menggunakan program Bioedit versi 6.05

adanya rotasi tanaman. Selain itu, penanaman dilakukan secara tidak serempak sehingga tanaman padi selalu ada sebagai makanan serangga wereng.

Gejala infeksi RRSV dan RGSV yang ditemukan di Sukamandi memiliki kesamaan dengan gejala yang dilaporkan oleh Du et al. (2005). Tanaman yang terinfeksi RRSV dan RGSV bersama-sama menunjukkan adanya gejala kerdil yang lebih parah dari infeksi tunggal, biasanya gejala RRSV muncul pertama dengan anakan berwarna hijau gelap, lebih pendek, lebih tipis dan tegak dengan anakan kecil-kecil, kemudian diikuti dengan munculnya gejala RGSV, yaitu daun muda menjadi lebih kecokelatan dan kadang terdapat daun tua yang menunjukkan adanya daun menguning. Pada penelitian ini tanaman singgang terbukti terinfeksi RGSV dan RRSV dan berpotensi menjadi sumber inokulum, sehingga sanitasi tanaman harus dilakukan sebelum tanam.

Metode deteksi secara molekuler dan analisis nukleotida RRSV dan RGSV belum pernah dilaporkan di Indonesia. Plant Protection Research Institute (PPRI) (2012) melaporkan primer spesifik yang digunakan untuk amplifikasi RRSV dan RGSV dengan metode PCR berbeda dengan primer yang digunakan pada penelitian ini. Amplifikasi RRSV menggunakan pasangan primer RRSV-F3/RRSV-R3 atauRRSV-F9/RRSV-R9 dengan target DNA berturut-turut $825 \mathrm{pb}$ dan $1110 \mathrm{pb}$; sedangkan untuk amplifikasi RGSV digunakan pasangan primer RGSV-P5F/ RGSV-P5R dengan target amplikon $885 \mathrm{pb}$. Target amplikon yang diperoleh lebih besar dibandingkan dengan target amplikon yang digunakan pada penelitian ini, yaitu $445 \mathrm{pb}$ untuk RRSV dan 738 pb untuk RGSV.

Analisis sikuen nukleotida virus padi telah banyak dilaporkan untuk virus tungro (Kano et al. 1992; Ordiz et al. 2010), tetapi masih sangat terbatas untuk virus kerdil pada padi. Pencarian sikuen RGSV dan RRSV pada Genbank berhasil mendapatkan masingmasing 4 sikuen isolat virus. Upadhyaya (1995) melaporkan bahwa RRSV isolat Thailand memiliki homologi yang tinggi dengan RRSV isolat India, yaitu 94.6\% dan $99.4 \%$ berturut-turut untuk sikuen nukleotida dan asam amino. Hasil analisis sikuen RGSV 
dilaporkan oleh Lianhui dan Qiying (2003), yaitu isolat RGSV-SX memiliki homologi sikuen nukleotida sebesar $99.1 \%$ dan $96.2 \%$ berturut-turut dengan isolat RGSV-IR dan RGSV-SC, sedangkan homologi sikuen asam amino sebesar 98.4\% dan 96.4\%. Kesamaan sikuen nukleotida yang tinggi $(>89 \%)$ antar isolat RGSV dan RRSV menjadi indikasi hubungan kekerabatan yang sangat dekat di dalam masing-masing grup (King et al. 2012).

Insidensi penyakit kerdil padi di Sukamandi masih bersifat sporadik, tetapi perlu diperhatikan terutama karena berkaitan dengan dinamika populasi serangga vektornya, wereng batang cokelat. Metode deteksi secara molekuler dengan RT-PCR dapat digunakan untuk memastikan infeksi RGSV dan RRSV pada tanaman padi. Analisis sikuen nukleotida menunjukkan hubungan kekerabatan RRSV dan RGSV isolat Indonesia yang dekat dengan beberapa isolat asal negara-negara di Asia, terutama Vietnam.

\section{UCAPAN TERIMA KASIH}

Penelitian ini didanai melalui hibah penelitian Kerjasama Kemitraan Penelitian dan Pengembangan Pertanian Nasional (KKP3N) dari Kementrian Pertanian (SPK no. 65/TL.220/I.1/3/2014.K).

\section{DAFTAR PUSTAKA}

Cabautan PQ, Cabunagan RC, Choi IR. 2009. Rice viruses transmitted by the brown planthopper Nilaparvata lugens Stal. Di dalam Heong KL, Hardy B, editor. Planthoppers: New Threats to the Sustainability of Intensive Rice Production Systems in Asia. Los Banos (PH): International Rice Research Institute.

Chen CC, Chiu RJ. 1982. Three symptomatologic types of rice virus diseases related to grassy stunt in Taiwan. Plant Dis. 66:15-18. DOI: http://dx.doi. org/10.1094/PD-66-15.

Doyle JJ, Doyle JL. 1990. A rapid total DNA preparation procedure for fresh plant tissue. Focus. 12:13-15.
Du PV, Cabunagan RC, Choi IR. 2005. Rice "yellowing syndrome" in Mekong River Delta. Omonrice. 13:135-138.

[IRRI] International Rice Research Institute. 2002. Standard Evaluation System of Rice (SES). Manila (PH): INGER Genetic Resources Center.

Kano H, Kozumi HM, Noda H, Hibino $\mathrm{H}$, Ishikawa $\mathrm{K}$, Omura $\mathrm{T}$, Cabauatan PQ, Koganezawa H. 1992. Nucleotide sequence of capsid protein gen of Rice tungro bacilliform virus. Arch Virol. 124(1-2):157-163. DOI: http://dx.doi. org/10.1007/BF01314633.

King AMQ, Adam MJ, Carstens EB, Lefkowitz EJ. 2012. Virus Taxonomy Classification and Nomenclature of viruses. Birmingham (US): Elsevier Academic Pr.

Lianhui LLWZX, Qiying L. 2003. Cloning, sequence analysis and procariotic expression of the vRNA3 NS3 gene in Rice grassy stunt virus Shaxian isolate. J Agric Biotech. 11(2):187-191.

Ordiz MI, Magnenat L, Barbas CF, Beachy RN. 2010. Negative regulation of the RTBV promoterby designed zinc finger proteins. Plant Mol Biol. 72(6):621-630. DOI: $10.1007 / \mathrm{s} 1103-010-9600.0$.

[PPRI] Plant Protection Research Institute. 2012. Rice Virus in Vietnam (Present status). Manila (PH): Plant Protection Research Institute.

Uehara-Ichiki T, Shiba T, Matsukura K, Ueno T, Hirae M. 2013. Detection and diagnosis of rice-infecting viruses. Front Microbiol. 4:289. DOI: http://dx.doi.org/10.3389/ fmicb.2013.00289.

Upadhyaya NM, Yang M, Kositratana W, Ghosh A, Waterhouse PM. 1995. Molecular analysis of rice ragged stunt oryzavirus segment 9 and sequence conservation among isolates from Thailand and India. Arch Virol. 140(11):19451956. DOI: http://dx.doi.org/10.1007/ BF01322684. 